\title{
ZUSES
}

science for a changing world

U.S. DEPARTMENT OF THE INTERIOR

U.S. GEOLOGICAL SURVEY

\section{Preliminary Report on Geophysical Data in Yavapai County, Arizona}

by V.E. Langenheim¹ , J .P. Hoffmann², K.W. Blasch², Ed Dewitt", and Laurie Wirt ${ }^{3}$

Open-File Report 02-352

2002

This report is preliminary and has not been reviewed for conformity with U.S. Geological Survey editorial standards or with the North American Stratigraphic Code. Any use of trade, firm, or product names is for descriptive purposes only and does not imply endorsement by the U.S. Government.

U.S. DEPARTMENT OF THE INTERIOR

U.S. GEOLOGICAL SURVEY

${ }^{1}$ Menlo Park, California

${ }^{2}$ Tucson, Arizona

${ }^{3}$ Denver, Colorado 


\section{TABLE OF CONTENTS}

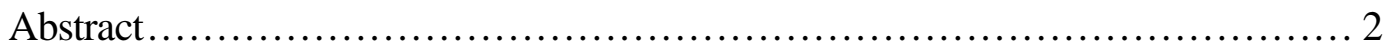

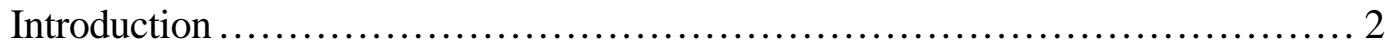

Geologic Setting .......................................................... 2

Aeromagnetic Data, Maps, and Derivative Products .......................... 5

About the Aeromagnetic Method .......................................... 5

Magnetic Lithologies...................................................... 6

Data Acquisition and Processing ......................................... 7

Aeromagnetic Map and Derivative Products ............................... 8

Shallow Geophysical Data ................................................. 10

Gravity Data and Map .................................................... 10

Surface Electromagnetic Surveys ....................................... 12

Seismic-Refraction Surveys ........................................... 14

Conclusions and Recommendations ....................................... 15

Acknowledgments......................................................... 16

References............................................................ 17

\section{FIGURES}

Figure 1. Shaded-relief topographic map of the study area...................20

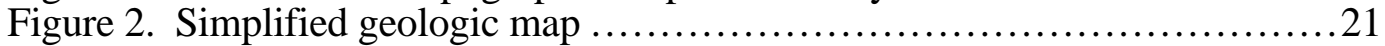

Figure 3. Cartoon of magnetic field ........................................ 22

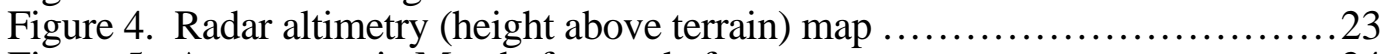

Figure 5. Aeromagnetic Map before and after............................... 24

Figure 6. Filtered ("residual") aeromagnetic map............................. 26

Figure 7. Magnetization boundaries on geologic map.........................27

Figure 8 . Gravity map ................................................ 28

Figure 9. Site map of shallow geophysical surveys.........................29

\section{TABLES}

Table 1. Depths of investigation using EM-34-3 instrument .................... 13

Table 2. Apparent electrical conductivity values .............................. 14

Table 3. Compressional wave velocity values ............................. 16 


\begin{abstract}
Recently acquired geophysical data provide information on the geologic framework and its effect of groundwater flow and on stream/aquifer interaction in Yavapai County, Arizona. High-resolution aeromagnetic data reflect diverse rock types at and below the topographic surface and have permitted a preliminary interpretation of faults and underlying rock types (in particular, volcanic) that will provide new insights on the geologic framework, critical input to future hydrologic investigations. Aeromagnetic data map the western end of the Bear Wallow Canyon fault into the sedimentary fill of Verde Valley. Regional gravity data indicate potentially significant accumulations of low-density basin fill in Big Chino, Verde, and Williamson Valleys. Electrical and seismic data were also collected and help evaluate the approximate depth and extent of recent alluvium overlying Tertiary and Paleozoic sediments. These data will be used to ascertain the potential contribution of shallow ground-water subflow that cannot be measured by gages or flow meters and whether stream flow in losing reaches is moving as subflow or is being lost to the subsurface. The geophysical data will help produce a more robust groundwater flow model of the region.
\end{abstract}

\title{
INTRODUCTION
}

This report summarizes the acquisition, data processing, and preliminary interpretation of a high-resolution aeromagnetic survey in Yavapai County, Arizona. The report also describes surface geophysical data (gravity, electromagnetic, and seismic-refraction) collected in the area. Yavapai County is one of the fastest-growing rural counties in the United States, with population growth concentrated in Verde Valley and in the vicinity of Prescott and Sedona. The rapid population growth has led to a concurrent increase in water resources development. Although the Verde River is a dominant source of surface water, groundwater serves as a major source of public and domestic water. In order to improve understanding of the geologic framework and its effect on groundwater flow, Yavapai County contracted a high-resolution aeromagnetic survey in 2001. Gravity data were collected to enhance existing coverage and provide additional information on basin structure. Shallow electromagnetic (EM) and seismic-refraction surveys were collected to determine the electrical and seismic properties of stream channel and adjacent floodplain deposits in selected areas of the Verde River watershed. This report will treat the geophysical methods separately. The interpretation presented here is preliminary.

\section{GEOLOGIC SETTING}

The aeromagnetic survey covers most of Yavapai County and augments the highresolution aeromagnetic survey centered on the headwaters of the Verde River that was flown in 1999 (Langenheim and others, 2000). The survey blocks include upper Big 
Chino Valley $\left(307 \mathrm{~km}^{2}\right.$ ), Cottonwood (Verde Valley; $1335 \mathrm{~km}^{2}$ ), the Black Hills (892 $\left.\mathrm{km}^{2}\right)$, the Prescott area $\left(872 \mathrm{~km}^{2}\right)$, and Williamson Valley $\left(324 \mathrm{~km}^{2}\right)$ (Fig. 1). The study area lies within the transition zone between the Colorado Plateau and the Basin and Range physiographic provinces. The transition zone exhibits geologic features that are common to both provinces. For example, regional projections indicate that Paleozoic strata are nearly continuous across the Colorado Plateau-transition zone boundary. Attitudes measured for the Paleozoic rocks indicate a regional dip of $<10^{\circ}$ toward the plateau; this regional dip is interrupted by steeper dips associated with monoclines (Krieger, 1965). The zone is also characterized by a series of Tertiary and Quaternary north- and northwest-trending normal faults (Menges and Pearthree, 1983; Reynolds, 1988), features that are characteristic of the the Basin and Range province.

The only available digital geology that covers the entire study area is the State of Arizona geology map, compiled by the Arizona Geological Survey (Richard and Kneale, 1998) at 1:1,000,000 and is the source of the geologic map shown in Figure 2. The geology of the Prescott National Forest, which includes the study area, is being compiled at a scale of 1:100,000 and will enhance any future geophysical interpretation efforts.

Rocks exposed in the study area consist of four main types and ages. Beginning with the oldest rocks, Precambrian igneous and metamorphic rocks form the basement complex of the area. These rocks are exposed in the mountain ranges that lie along the southern (Bradshaw Mountains) and western (Juniper and Santa Maria Mountains) fringes of the study area (Anderson and Blacet, 1972a). Precambrian rocks also are extensively exposed in the Black Hills in the south-central part of the study area. Isolated Precambrian metasedimentary and igneous rocks are also exposed in the area (e.g., $2 \mathrm{~km}$ east of Del Rio Springs and the outcrops at the northern end of the Big Chino fault). The Precambrian rocks are overlain by Cambrian to Permian sedimentary rocks, throughout much of the area, although the Paleozoic rocks have been stripped away in much of Lonesome Valley and parts of the Black Hills (Krieger, 1965). The thickness of the Paleozoic sequence ranges from zero in parts of the Black Hills and Little Chino Valley to as much as $1330 \mathrm{~m}$ (4375 feet).

A major unconformity and long period of erosion separate the third and fourth groups of rocks, consisting of Tertiary and Quaternary sedimentary and volcanic rocks, from the underlying Paleozoic sequence. Extensive Tertiary sedimentary rocks are exposed in the valley areas. Along the margins of Lonesome Valley, Tertiary fanglomerate, mud flow deposits, and tuffaceous deposits are exposed; towards the interior of the basin, these rocks also include channel gravel, sand, silt, clay and marl. Tertiary sedimentary rocks both 
underlie and overlie, and in places, are interbedded with, Tertiary volcanic rocks. Tertiary volcanic rocks consist of two main lithologies, basalt and latite. Latite is extensively exposed at Sullivan Buttes (Tyner, 1984), whereas basalt outcrops throughout the study area and is inferred to underlie much of Lonesome and Verde Valleys. The thickness of the volcanic rocks varies from as little as 15 to $400 \mathrm{~m}$ in the Black Hills (Anderson and Creasey, 1958). Well log data in Lonesome Valley suggest that the upper surface of the volcanic rocks ("malpais or malapais" in driller's logs and inferred to be basalt) slopes gently to the southwest from the northeast side of the basin (Krieger, 1965). The maximum thickness of the basalt penetrated in wells in Lonesome Valley is $150 \mathrm{~m}(500 \mathrm{ft})$. In Verde Valley, the Tertiary volcanic rocks are overlain by the lakebed deposits of the Mio-Pliocene Verde Formation (Holm and others, 1998; Leighty, 1998). These rocks were deposited in a valley similar in size to the present Verde Valley and consists of limestone, mudstone, sandstone, and, locally, evaporite deposits. The thickness of the Verde Formation is poorly known, but may be as great as $670 \mathrm{~m}$ (Twenter and Metzger , 1963).

The most intense and complexly deformed rocks in the area are the Precambrian rocks (Anderson and Creasey, 1958; Anderson and Blacet, 1972a, b; Anderson, 1989; DeWitt, 1987, 1989; Wilson, 1939). This deformation, which produced folds (isoclinal in the older Precambrian rocks), foliation, and faults, did not affect the Paleozoic sequence. The Paleozoic rocks generally dip less than $10^{\circ}$ to the northeast in the study area, except near monoclines (e.g. the Big Chino monocline on Big Black Mesa). The age of these monoclines is probably Late Cretaceous to early Tertiary in age. Northeast of the study area is the Mormon Mountain anticline which produces nearly $500 \mathrm{~m}$ of relief along very gently dipping limbs (4 $4^{\text {; }}$ Twenter and Metzger, 1963) with respect to the Paleozoic sequence in Verde Valley. Gravels exposed in the headwaters area of the Verde River are evidence for a northeast sloping erosion surface (Elston and Young, 1991). Remnants of these gravels exposed elsewhere suggest that this erosional surface developed before the older sequence of basalts erupted. Extensional faulting resulted in large-scale downdropping of Tertiary volcanic and sedimentary rocks in Verde Valley at about 11-8 Ma (Elston and Young, 1991). Presumably, faulting also occurred west of the Black Hills at about the same time, but with less offset than that to the east. Much of the resultant topography was later filled in with younger basalts.

Several faults in the Transition zone show evidence of multiple ages of movement. Shoemaker and others (1978) show several northeast- and northwest-trending fault systems in northwestern Arizona that are Tertiary in age and parallel the Precambrian 
structural grain. A fault system identified by Krieger (1965) and Shoemaker and others (1978) is the northwest-trending Big Chino fault, exposed along the southwestern edge of Big Black Mesa (Figs. 1, 2). This fault clearly shows evidence of movement as young as Quaternary (Menges and Pearthree, 1983). The Big Chino fault may have been responsible for the February 4, 1976 Chino Valley earthquake $\left(M_{b}=4.9\right)$, analysis of which indicated normal movement along a northwest-trending fault plane dipping $40^{\circ}$ to the southwest (Eberhart-Phillips and others, 1981).

Another fault zone, the Verde fault zone, shows evidence of Quaternary movement (Pearthree, 1998). It forms a northwest-striking zone of faults along the western margin of Verde Valley, progressively downdropping to the east. Anderson and Creasey (1958) suggested that as much as $300 \mathrm{~m}$ of offset on this fault may have occurred during the Precambrian. Most of the offset took place during the late Miocene and Pliocene (Bressler and Butler, 1978; Nations and others, 1981), displacing Tertiary rocks as much as $1000 \mathrm{~m}$ (Twenter and Metzger, 1963). Evidence of Quaternary offset is limited to an 8-km-long section of fault scarps in the southern part of the fault zone, called the "Camp Verde" fault by Menges and Pearthree (1983).

Faults often serve as conduits or barriers to ground-water movement. On a regional scale, northwest -trending fractures throughout the Colorado Plateau area in northern Arizona (Shoemaker and others (1978) tend to be open to fluid flow (Thorstenson and Beard, 1998; L.S. Beard, oral commun., 1999). Twenter and Metzger (1963) argue that the Verde fault zone acts as a barrier to groundwater flow and directs groundwater to the southeast along its fractures and joints. Owen-Joyce and Bell (1983, p. 20) report that well yields in the Middle Verde basin are generally improved by the presence of solution cavities along fractures in the Redwall Limestone and Martin Limestone. These limestone units are exposed along the margins of the Big Chino basin and the canyon walls of the upper Verde River (Fig. 2). Wirt and Hjalmarson (2000) propose that the northwest-trending Big Chino fault, which offsets the Paleozoic limestones along the base of Big Black Mesa (Fig. 2), serves as a conduit for ground-water exiting Big Chino Basin and supplying base flow to the upper Verde River.

\section{AEROMAGNETIC DATA, MAPS, AND DERIVATIVE PRODUCTS}

\section{About the Aeromagnetic Method}


Geologic structures (such as faults or igneous intrusions) often produce small magnetic fields that distort the main magnetic field of the Earth (Fig. 3). These distortions, called anomalies, can be detected by measuring the intensity of the Earth's magnetic field on or near the surface of the earth. By analyzing magnetic measurements, geophysicists are able to learn about geologic structures, even though these structures may be buried beneath the Earth's surface (e.g., Dobrin and Savit, 1988; Blakely, 1995). Magnetic measurements are often made from airplanes (or helicopters) flown along closely spaced, parallel flight lines. Additional flight lines are flown in a perpendicular direction to aid in data processing. These measurements are then processed into a digital "aeromagnetic" map. Assisted by computer programs, the geophysicist builds a geologic interpretation from these data, incorporating geologic mapping, well information, and other available geophysical information (e.g., gravity, radiometric, electrical, seismic-reflection).

\section{Magnetic Lithologies}

Volcanic rocks are the most prevalent magnetic lithology of this region, and we expect high-amplitude, short-wavelength anomalies over volcanic terranes, especially in the Black Hills and the area between Page Springs and Sedona. Volcanic rocks in the area consist of (1) the Sullivan Buttes latite (24-26 Ma; also known as the andesite unit of Krieger, 1965), (2) an older sequence of basalts of the Hickey Formation, and (3) a younger section of basalts of the Perkinsville Formation. The basalts in this region typically include lava flows which individually may have a uniform direction of magnetization. Steeply dipping faults that offset subhorizontal units often produce magnetic anomalies that appear as linear trends on aeromagnetic maps (e.g., Bath and Jahren, 1984). The latites, on the other hand, often are extruded from volcanic plugs and thus tend to produce intense, somewhat circular magnetic anomalies (often as magnetic lows, because the latites are generally reversely polarized). The latites are exposed at Sullivan Buttes and are inferred to underlie parts of Little Chino Valley (Langenheim and others, 2000).

The magnetic properties of sedimentary rocks, such as the Paleozoic sequence of dolomite, limestone, and sandstone, are usually weak, such that the resulting magnetic anomalies are very small in amplitude or undetectable by airborne surveys. The Precambrian metasedimentary rocks are generally incapable of producing detectable magnetic anomalies, although there are some notable exceptions. Exceptions include an iron-rich metachert that forms a minor lithologic constituent exposed south of the towns of Prescott and Prescott Valley (Krieger, 1965) and metagraywacke exposed on the western 
side of Sullivan Buttes. Metavolcanic rocks, gabbros and some of the intrusive rocks can produce prominent magnetic anomalies. Magnetic susceptibility is a measure of how magnetic a rock becomes when placed in an external magnetic field and is mostly a function of the amount of magnetite in that rock. Magnetic susceptibility measurements of Precambrian metavolcanic rocks range from 2 (meta-rhyolite) to 8000 (metabasalt) $10^{-6} \mathrm{SI}$ units (Ed DeWitt, written commun., 2000). Gabbros also show a high range in susceptibility for 29 samples, from 30 to $8000 \times 10^{-6}$ in the SI system. Granodiorites and granites show a wide range in susceptibility, although individual granodiorite and granite plutons are characterized by narrower ranges in susceptibility. For example, the Prescott granodiorite has a range of 900 to $1600 \times 10^{-6}$ for 6 samples (mean of $1100 \times 10^{-6}$ ). The Minnehaha granodiorite, on the other hand, is less magnetic, showing a range in susceptibility of 10 to $350 \times 10^{-6}$ for 5 samples (mean of $48 \times 10^{-6}$ ).

\section{Data Acquisition and Processing}

Goldak Airborne Survey conducted the aeromagnetic survey under contract to Yavapai. County. Goldak is headquartered in Saskatoon, Sasketchewan, Canada, and has years of experience in acquiring and processing aeromagnetic data. Data acquisition and processing were accomplished under guidelines established by the U.S. Geological Survey over the last several decades.

The aeromagnetic data were acquired with a Piper PA-31 Navajo, a fixed-wing aircraft. The airborne magnetic sensor was a Geometrics G-822A cesium-vapor magnetometer located at the tip of a fiberglass stinger (boom). A theoretical flight surface, based on a digital topograhic model, was computed in advance of the survey, and a real-time, differentially corrected Global Positioning System (GPS) was used during flight to maintain this theoretical surface. Flight lines were oriented east-west and flown at a nominal altitude of $150 \mathrm{~m}$ (500 ft) above terrain, or as low as permitted by the Federal Aviation Adminstration and safety considerations. Figure 4 shows the height of the airplane above the ground measured by radar altimetry. The Prescott, Williamson Valley, and most of the Black Hills and Cottonwood blocks were flown at a flightline spacing of $200 \mathrm{~m}$. The Upper Big Chino block and the northern parts of the Black Hills and Cottonwood blocks were flown at a spacing of $300 \mathrm{~m}$. North-south control lines were spaced $3.0 \mathrm{~km}(1.83 \mathrm{mi})$ apart. Total flight distance was 21,691 km (13,478 mi).

Two base station magnetometers were deployed for this survey. The primary base station, a cesium-vapor magnetometer identical to the airborne sensor, was just east of 
Prescott. The secondary base station, a proton-precession magnetometer, was located at the Ernest Love municipal airport north of the city of Prescott. A base station magnetometer measures the time-varying magnetic field and has two important functions: (1) it records the normal daily changes of the external field (diurnal variation), which are subtracted from the aeromagnetic data and (2) it records the onset and dissipation of magnetic storms. Airborne operations were interrupted if magnetic storm activity exceeded the limits established by the U.S. Geological Survey. The limits were as follows: (a) 5 nanoteslas (nT) for monotonic changes during any 5 minute period, (b) $2 \mathrm{nT}$ for pulsations with periods of 5 minutes or less, (c) 4 nT for pulsations with periods between 5 and 10 minutes, and (d) $8 \mathrm{nT}$ for pulsations with periods between 10 and 20 minutes. Time between aircraft and base stations was synchronized with GPS time.

Post-survey data processing was performed by Patterson, Grant and Watson (PGW) of Toronto, Canada. This included removal of diurnal fields, subtraction of the International Geomagnetic Reference Field (e.g., Barton and others, 1996), navigational corrections, and adjustment of total-field values between crossings of flight lines and tie lines. A preliminary version of the completed survey was provided to the USGS for evaluation in September, 2001. Final data were delivered in November, 2001. Accuracy of the data is estimated to be on the order of 0.5 to $1 \mathrm{nT}$.

\section{Aeromagnetic Map and Derivative Products}

Figures $5 \mathrm{a}$ and $5 \mathrm{~b}$ show the improved resolution of the new, high-resolution data compared to the preexisting, regional aeromagnetic data. Color scale in these maps indicates the intensity of the Earth's magnetic field relative to a global standard (the International Geomagnetic Reference Field updated to the date of the survey). The regional digital coverage (Sweeney and Hill, 2001) consists of east-west flightlines flown at a spacing of 1 or 3 miles and data from 3 higher-resolution surveys (Dempsey and Hill, 1963; USGS, 1981; USGS, 1982). We also incorporated the high-resolution aeromagnetic survey that covers the headwaters region of the Verde River (Langenheim and others, 2000). Figure 5b shows the new survey merged into the regional digital database. As expected, volcanic regions produce distinctive magnetic anomalies, high in amplitude and short in wavelength. These anomalies are particularly evident over much of Lonesome Valley, the Black Hills and the area between Cornville and Sedona. For example, the preexisting regional coverage indicates only a broad magnetic high in the Page Springs area 
(Fig. 5a). Virtually all of the individual magnetic anomalies seen in the new highresolution data (Fig. 5b) are absent in the pre-existing regional coverage.

Large magnetic highs are present over the weakly magnetic Paleozoic sedimentary rocks exposed on Big Black Mesa and in the vicinity of Sedona. Thus, the sources of these anomalies are likely concealed by Paleozoic units. Krieger (1967a) shows several small exposures of Precambrian granitic rocks along the Big Chino fault; these rocks are the most likely source of the Big Black Mesa magnetic high. The high is truncated by the Big Chino fault on its southwestern margin (Langenheim and others, 2000). Oil-test wells in the Sedona area encountered Precambrian granite beneath 300-500 m of Paleozoic sedimentary rocks (Peirce and Scurlock, 1972); Precambrian crystalline basement is the most likely source of the broad magnetic high in the Sedona area. The long-wavelength nature of the magnetic high indicates that the source of the anomaly is buried.

Subdued magnetic anomalies are present in the Verde Valley. The subdued nature of these anomalies is probably caused by two factors: (1) the increased height of the magnetic sensor above the ground surface in this region (Fig. 4) and (2) the increased thickness of relatively non-magnetic Verde Formation in the downdropped block of the Verde fault zone. To emphasize and sharpen the anomalies in this region, filtering of the data and comparison to the gravity data will be needed.

The new aeromagnetic data are of sufficient quality to permit the application of wellestablished processing and filtering techniques that emphasize subtle features. Figures 6 and 7 show the aeromagnetic data processed to enhance and define near-surface sources. Figure 6 shows "residual magnetic anomalies", a technique that emphasizes shallow magnetic sources. This residual magnetic map was computed by analytically continuing the aeromagnetic data to a slightly higher surface (100 m; Blakely, 1995), in other words, mathematically transforming the data as if they were collected at a higher altitude, and then subtracting that result from the original data. The anomalies that remain are commonly called residual magnetic anomalies. This method, essentially a discrete vertical derivative, emphasizes anomalies caused by shallow magnetic sources (approximately $<1 \mathrm{~km}$ ) while subduing anomalies caused by deep sources. It is particularly useful in identifying shallow crustal faults that separate rocks of contrasting magnetic properties. Shallow sources produce short-wavelength anomalies, such as the anomalies present over exposed volcanic rocks.

Subtle magnetic anomalies that are not apparent in Figure 5b are accentuated in the filtered aeromagnetic data (Fig. 6). The magnetic field over the alluvial deposits of Lonesome Valley shows several northwest- and north-trending anomalies. Because 
alluvium is often weakly magnetic, some of these anomalies may originate from volcanic rocks concealed beneath the surface. Other possible sources are shallowly buried Precambrian basement, or alteration along buried fault zones. A linear, north-striking magnetic high extends from the town of Prescott Valley north towards Perkinsville. Its source probably resides within the Precambrian basement, because the magnetic anomaly can be traced onto Precambrian rocks.

Figure 7 shows magnetization boundaries, automatically computed from the aeromagnetic data (Blakely and Simpson, 1986). This calculation assumes that magnetic contacts are vertical; calculated positions will be shifted slightly over contacts that are not vertical. Figure 7 shows the magnetization boundaries plotted on the regional geology. Langenheim and others (2000) used the magnetization boundaries to map the extent of the Big Chino Fault, as indicated by a lineament on the basin margin of Big Black Mesa. The new data extend the Big Chino fault to the north of the 1999 high-resolution aeromagnetic survey and are consistent with Krieger's (1967b) geologic mapping of the fault. The magnetic data can also be used to extend the Bear Wallow Canyon fault west of its mapped extent into the northern part of Verde Valley.

The magnetization boundaries also define structures related to buried volcanic rocks. For example, the magnetization boundaries in the northeast corner of the Upper Big Chino block delineate the extent of buried basalt (possibly a northeast-striking paleochannel filled with basalt?) on the upthrown side of the Big Chino fault. Future analysis should focus on establishing the depth, thickness, and geometry of the volcanic rocks beneath upper Big Chino, Lonesome, Verde, and Williamson Valleys.

\section{SURFACE GEOPHYSICAL DATA}

\section{Gravity data and map}

As part of this project, we compiled and reprocessed the existing gravity coverage of the region (National Geophysical Data Center, 1999; Frank, 1984; Smith, 1984;

Langenheim and others, 2000) and added 628 new gravity stations using a global positioning system (GPS) to determine location and elevation. These data have been processed to provide information on subsurface density variations. The gravitational attraction at any point depends on many factors, including the latitude and elevation of the measurement, earth tides, terrain, deep masses that isostatically support the terrain, and variations in density within the Earth's crust and upper mantle. The last of these quantities is of primary interest in geologic investigations and can be obtained by calculating and 
removing all other quantities. The resulting field is called the isostatic residual gravity anomaly and reflects, to first order, density variations within the middle and upper crust (Simpson and others, 1986).

The gravity field is dominated by gravity highs along the northeastern part of the study area, with lower gravity values in the southwestern part of the study area (Fig. 8). Superposed on this regional field are local gravity lows in the valley areas. Big Chino Valley is characterized by a gravity low, bounded on the east by the Big Chino Fault. The deepest part of the basin, as suggested by the lowest gravity value within the valley (-24 $\mathrm{mGal}$ ), is about $5 \mathrm{~km}$ from the southern edge of the Upper Big Chino aeromagnetic survey block. Gravity values increase to the southeast towards Sullivan Lake. The northern part of Lonesome Valley is characterized by higher gravity values than those over Big Chino Valley, suggesting that the basin fill beneath Little Chino Valley is less than $1 \mathrm{~km}$ (Langenheim and others, 2000). South of the town of Chino Valley is an east-west striking gravity gradient, with a large gravity low to the south. This low could be caused by a deep basin centered near the intersection of Highway 89 and alternate route 89 , but a more likely explanation is a thick stock of Prescott granodiorite (Cunion, 1985). The gravity low extends over Precambrian rocks and Prescott granodiorite (and Granite Dells granite) is less dense than the some of the more mafic metavolcanic and gabbros within Precambrian basement.

A gravity feature of potential hydrologic interest is the gravity low over Williamson Valley. The gravity low may reflect either a relatively deep $(1-2 \mathrm{~km})$ sedimentary basin or a low-density pluton (Langenheim and others, 2000). The margins of the low are linear and strike northwest. The gravity low also coincides with a magnetic low (Fig. 5b, 6). The basin interpretation is preferred because the gravity low does not extend across Precambrian outcrops exposed to the east of the gravity low. A drillhole recently (2002) completed for the city of Prescott supports the basin interpretation; the drillhole penetrated $460 \mathrm{~m}$ (1500 ft) without encountering basement rocks (T. Merrifield, oral commun., 2002; Fig.T\&e Verde Valley is also characterized by a northwest-trending gravity low. Based on the amplitude of the gravity low $(15-18 \mathrm{mGal})$ and assuming a reasonable density contrast between the basin fill and the basement rocks $\left(-0.4 \mathrm{~g} / \mathrm{cm}^{3}\right)$, the basin fill may be as thick as $1 \mathrm{~km}$. The low, approximately $35 \mathrm{~km}$ long and 8-10 km wide, lies within the western half of the valley. The western margin of the Verde Valley gravity low is nearly coincident with the southern part of the Verde fault zone, but lies 1-2 km east of the mapped trace of the northern part of the fault zone. The eastern margin of the basin is more linear, suggestive of a fault origin, and steps to the southwest near the intersection of I-17 and Hwy 260, 
dividing the gravity low into two parts. The lowest gravity values are northwest of the step. A smaller gravity low, about $8 \mathrm{~km}$ long, lies to the south of the step. The southern extent of this gravity low is poorly constrained by existing gravity data.

Another gravity feature of potential hydrologic interest is outside the study area, in the southwest corner of Figure 8, where the lowest gravity values lie northeast of the intersection of highways 89 and 96 . Although the gravity feature is poorly constrained, the low appears to be caused by thick sedimentary fill. Two drillholes, 518 and $669 \mathrm{~m}$ deep (1700 and $2195 \mathrm{ft}$, respectively), did not penetrate basement (Oppenheimer and Sumner, 1980).

\section{Surface Electromagnetic (EM) Surveys}

Surface EM methods measure the apparent electrical conductivity of subsurface deposits, which help evaluate the approximate depth and extent of recent alluvium. The depth extent of these data is shallow ( $<75 \mathrm{~m}$ ), which complements the generally more regional nature and deeper depth of investigation obtained from the gravity data. The apparent electrical conductivity of the deposits is a function of grain size, composition, and moisture content. Conductivity values for dry alluvium in the arid Southwest commonly are less than 10 millimhos per meter (mmhos/m) but can range from 20 to $50 \mathrm{mmhos} / \mathrm{m}$ when saturated; those of saturated clay and silt commonly are about $100 \mathrm{mmhos} / \mathrm{m}$ or greater. Paleozoic sandstones and limestones have conductivity values less than 20 and commonly less than $10 \mathrm{mmhos} / \mathrm{m}$. Basalt units can be one of the least conductive rock units depending on degree of weathering and water content; generally, conductivity values are less than five mmhos/m.

Depth of investigation for the EM34-3 instrument used during these surveys (Fig. 9) ranges from about 7.5 to $60 \mathrm{~m}$ and is a function of transmission frequency, coil spacing, and dipole type (Table 1). Although depth of investigation for the electromagnetic-induction instruments extends to about $60 \mathrm{~m}$, depth of the material contributing to the signal differs

\begin{tabular}{|c|c|c|c|}
\hline \multirow{2}{*}{$\begin{array}{l}\text { Frequency, } \\
\text { in hertz }\end{array}$} & \multirow{2}{*}{$\begin{array}{c}\text { Coil spacing, } \\
\text { in meters }\end{array}$} & \multicolumn{2}{|c|}{ Maximum depth of investigation, in meters } \\
\hline & & Vertical Dipole & Horizontal Dipole \\
\hline 6,400 & 10 & 15 & 7.5 \\
\hline
\end{tabular}




\begin{tabular}{|l|l|l|l|}
\hline 1,600 & 20 & 30 & 15 \\
\hline 400 & 40 & 60 & 30 \\
\hline
\end{tabular}

Table 2. Apparent electrical conductivity values (in $\mathrm{mmhos} / \mathrm{m}$ ) for soundings along Verde River and tributaries (Fig. 9).

\begin{tabular}{|c|c|c|c|c|c|c|c|c|}
\hline \multirow{3}{*}{$\begin{array}{l}\text { Area } \\
\text { Above Sycamore } \\
\text { Creek } \\
\text { Stewart Ranch }\end{array}$} & $\begin{array}{l}\text { Latitude } \\
\text { dms }\end{array}$ & $\begin{array}{l}\text { Longitude } \\
\text { dms }\end{array}$ & $\begin{array}{l}\text { 10-mete } \\
\text { Vertical } \\
\text { dipole }\end{array}$ & $\begin{array}{l}\text { spacing } \\
\text { Horizontal } \\
\text { dipole }\end{array}$ & $\begin{array}{l}\text { 20-mete } \\
\text { Vertical } \\
\text { dipole }\end{array}$ & $\begin{array}{l}\text { spacing } \\
\text { Horizonta } \\
\text { dipole }\end{array}$ & \multicolumn{2}{|c|}{$\begin{array}{l}\text { 40-meter spacing } \\
\text { I Vertical Horizontal } \\
\text { dipole dipole }\end{array}$} \\
\hline & 345112.2 & 112413.9 & 4 & 3 & 3 & 2 & 6 & 2 \\
\hline & 34528.7 & 112244.2 & 25.2 & 21.2 & 25 & 23.2 & 14.5 & 20 \\
\hline Stewart Ranch & 34529.3 & 112244.9 & 30.4 & 24 & 24.5 & 26.8 & 15.2 & 22.4 \\
\hline Stewart Ranch & 345210.2 & 112245.6 & 33.1 & 27.1 & 29.4 & 30.9 & 14.9 & 25.6 \\
\hline Stewart Ranch & 345211.2 & 112246.1 & 34 & 29 & 28.6 & 32.6 & 12.2 & 27.2 \\
\hline Stewart Ranch & 345211.9 & 112246.7 & 33.1 & 31.5 & 29.4 & 34.9 & 19.1 & 27.5 \\
\hline Stewart Ranch & 345212.7 & 112247.4 & 32.7 & 33 & 23.9 & 36.6 & 17 & 30 \\
\hline Stewart Ranch & 345213.6 & 112248.2 & 33.7 & 31.7 & 28.9 & 36 & 16.9 & 30.2 \\
\hline Granite Creek & 345112.6 & 1122543.5 & 7.2 & 6.6 & 5.1 & 5.1 & 1.5 & 1 \\
\hline Granite Creek & 345124.5 & 1122552.9 & 18.9 & 13.7 & 11.7 & 13.8 & 3.7 & 8.1 \\
\hline Granite Creek & 345132.1 & 1122555.9 & 12.3 & 20.8 & 4.9 & 16.8 & & 8.3 \\
\hline Granite Creek & 34510.7 & 1122526.2 & 11.7 & 11.9 & 9.7 & 9.8 & 5.5 & 6.7 \\
\hline Granite Creek & 345041.8 & 1122526.9 & 8.7 & 7.8 & 5.8 & 6.8 & 4 & 2.2 \\
\hline Granite Creek & 344955.4 & 1122534.7 & 26.3 & 25.9 & 22 & 28.1 & 14.5 & 21 \\
\hline Granite Creek & 344943.9 & 1122525.3 & 13 & 15.4 & 15.2 & 17 & 19.1 & 17.7 \\
\hline Granite Creek & 34503.8 & 1122535.4 & 6.5 & 6 & 6.6 & 5.2 & 9 & 2.3 \\
\hline Granite Creek & 345026.1 & 1122534.0 & 9.7 & 7.4 & 8.1 & 7.4 & 4.6 & 5.7 \\
\hline Granite Creek & 34516.6 & 1122546.8 & 7.4 & 9.2 & 5.7 & 6.1 & 2.5 & 1.5 \\
\hline Granite Creek & 34512.9 & 1122533.4 & 11.2 & 8.7 & 11 & 7.9 & 8.3 & 2 \\
\hline Stewart Ranch & 345156.1 & 1122425.6 & 26.5 & 22.2 & 19.5 & 19.7 & 9.3 & 18.6 \\
\hline Stewart Ranch & 345221.2 & 1122344.5 & 11.7 & 11.4 & 16.2 & 12.8 & 15 & 14.4 \\
\hline $\begin{array}{l}\text { Paulden stream } \\
\text { gage } \\
\text { Paulden stream }\end{array}$ & 345342.6 & 1122033.4 & 12.6 & 13.6 & 9.2 & 11.9 & 7.2 & 7.2 \\
\hline gage & 345342.8 & 1122031.4 & 15.5 & 16.5 & 12.8 & 15.5 & 8 & 13.4 \\
\hline $\begin{array}{l}\text { gage } \\
\text { Paulden stream }\end{array}$ & 345343.2 & 1122029.5 & 12.8 & 14 & 13.6 & 13.4 & 9.6 & 11.5 \\
\hline gage & 345342.1 & 1122028.6 & 10.4 & 9.7 & 9.5 & 9.8 & 9.5 & 7.5 \\
\hline $\begin{array}{l}\text { gage } \\
\text { Paulden stream }\end{array}$ & 345341.7 & 1122030.4 & 13.8 & 10.2 & 13.3 & 10.1 & 8.6 & 8 \\
\hline gage & 345341.3 & 1122032.5 & 14.7 & 10.8 & 15.6 & 11.5 & 11.9 & 10 \\
\hline & Measurem & from a $s$ & e volun & epresel & redo & itly Ter & 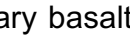 & osits. \\
\hline & $\begin{array}{l}\text { Measurem } \\
\text { stream-ch }\end{array}$ & $\begin{array}{l}\text { s from a sé } \\
\text { el and floo }\end{array}$ & $\begin{array}{l}\text { le volume } \\
\text { lain depo }\end{array}$ & $\begin{array}{l}\text { e representir } \\
\text { sits. }\end{array}$ & predo & antly sat & ed ar & unsaturated \\
\hline & $\begin{array}{l}\text { Measureme } \\
\text { limestone } \\
\text { Measureme } \\
\text { and flood p }\end{array}$ & $\begin{array}{l}\text { nts from a san } \\
\text { eposits. } \\
\text { nts from a san } \\
\text { ain deposits, }\end{array}$ & ple volume & e representin & ng predon & lantly Paleo & Jzoic san & $\begin{array}{l}\text { dstone and } \\
\text { n-channel }\end{array}$ \\
\hline
\end{tabular}

for each dipole type. For example, the material at a depth of about 0.4 times the coil spacing provides the maximum contribution to the signal for the vertical dipole (the near- 
surface material contributes little to the signal). Conversely, for the horizontal dipole, the near-surface materials are the most influential and decrease monotonically with depth (McNeill, 1980).

Apparent electrical conductivity data were collected from 27 EM34-3 soundings and are presented in Table 2. Apparent electrical conductivity values range from 1 to $37 \mathrm{mmhos} / \mathrm{m}$. Tertiary basalt deposits surveyed above Sycamore Creek exhibited the lowest conductivity values of $6 \mathrm{mmhos} / \mathrm{m}$ and smaller. The highest conductivity values were measured in the saturated stream-channel and floodplain deposits near Stewart Ranch, generally having conductivities greater than $20 \mathrm{mmhos} / \mathrm{m}$. The Paleozoic deposits ranged from 1 to 30 $\mathrm{mmhos} / \mathrm{m}$ but averaged about $12 \mathrm{mmhos} / \mathrm{m}$.

\section{Seismic-Refraction Surveys}

Seismic-refraction surveys (Fig. 9) were used to estimate the thickness of the streamchannel and adjacent floodplain deposits that overlie the Tertiary and Paleozoic rock units. Like the EM surveys, the depth of investigation is shallow $(<75 \mathrm{~m})$ and complements the gravity method. Sediments tend to be more compacted with increasing depth and therefore tend to transmit pressure waves at increasingly higher velocities. The velocity contrast between layers produces a refracted pressure wave that is detected by a line of geophones installed at the land surface. Seismic surveys were used to delineate the contact between the recent stream-channel deposits (and alluvium) and the older, more compacted and often consolidated, Tertiary and Paleozoic units.

Seismic data collected along 12 survey lines are presented in Table 3. Two energy sources were used to produce the pressure-wave signal. For shallow investigations (upper $30 \mathrm{~m}$ ), a 6 to 8-pound sledgehammer was used as the signal source; explosive charges were used for deeper investigations (to depths of about $75 \mathrm{~m}$ ). Geophone spacings ranged from 1 and $3 \mathrm{~m}$. A 48-channel digital seismograph was used to record the data from the refraction surveys. Data were analyzed using software by Rimrock Geophysics Inc. (1995) to determine the thickness of the recent stream-channel and floodplain deposits, and the seismic velocity of these deposits and the underlying Paleozoic units

Velocity values for unsaturated alluvium are less than those for saturated alluvium and Paleozoic units. Measured velocity values for unsaturated recent alluvium ranged from 250 to $720 \mathrm{~m} / \mathrm{s}$ and averaged $470 \mathrm{~m} / \mathrm{s}$; values for saturated alluvium ranged from 1,700 to $3,100 \mathrm{~m} / \mathrm{s}$ and averaged 2,200 m/s (table 3). Velocity values for the Paleozoic units ranged from 2,300 to $9,600 \mathrm{~m} / \mathrm{s}$ and averaged $3,900 \mathrm{~m} / \mathrm{s}$. The highest velocity values measured 
were in the lower reaches of Granite Creek where Paleozoic Martin Limestone and Tapeats Sandstone are exposed at the surface near the seismic line. Thickness of the streamchannel deposits and floodplain deposits ranged from 1 to $40 \mathrm{~m}$.

\begin{tabular}{|c|c|c|c|c|c|c|}
\hline Area & $\begin{array}{l}\text { Latitude } \\
\text { (dms) }\end{array}$ & $\begin{array}{l}\text { Longitude } \\
\text { (dms) }\end{array}$ & \begin{tabular}{|c|} 
Unsaturated \\
alluvium \\
velocity \\
$(\mathrm{m} / \mathrm{s})$
\end{tabular} & $\begin{array}{l}\text { Saturated } \\
\text { alluvium } \\
\text { velocity } \\
(\mathrm{m} / \mathrm{s}) \\
\end{array}$ & \begin{tabular}{|c|} 
Consolidated \\
Paleozoic unit \\
velocity \\
$(\mathrm{m} / \mathrm{s})$ \\
\end{tabular} & $\begin{array}{l}\text { Range in } \\
\text { thickness of } \\
\text { alluvium } \\
\text { (m) }\end{array}$ \\
\hline Stewart Ranch & 345214.0 & 1122404.6 & 400 & 1900 & 2300 & $15-25$ \\
\hline Paulden gage & 345341.7 & 1122030.4 & 670 & 2950 & 3800 & $5-20$ \\
\hline Paulden gage & 345342.5 & 1122033.6 & 720 & 3100 & 3300 & $5-15$ \\
\hline Perkinsville & 345341.9 & 1121225.7 & 800 & 1800 & 2300 & $5-15$ \\
\hline Bull Basin & 345253.7 & 1121916.3 & 340 & 1800 & 2800 & $3-20$ \\
\hline $\begin{array}{l}\text { Williamson Valley } \\
\text { Wash }\end{array}$ & 345159.5 & 1123645.0 & 540 & 2600 & 4900 & $5-40$ \\
\hline Granite Creek & 345136.6 & 1122559.1 & 400 & 1900 & 4300 & $>10$ \\
\hline Granite Creek & 345105.0 & 1122545.0 & 310 & 2300 & 3200 & $3-15$ \\
\hline Granite Creek & 345104.2 & 1122531.4 & 250 & 1900 & 4300 & $>10$ \\
\hline Granite Creek & 345055.2 & 1122524.6 & 300 & 2400 & Not detected & -- \\
\hline Granite Creek & 345132.1 & 1122554.2 & 390 & 2100 & 9600 & $3-8$ \\
\hline Dry Beaver Creek & 344344.0 & 1114634.0 & 570 & 1700 & 2500 & $1-10$ \\
\hline
\end{tabular}

\section{CONCLUSIONS AND RECOMMENDATIONS}

High-resolution aeromagnetic data in much of Yavapai County reflect diverse rock types at and below the topographic surface. These data have permitted a preliminary interpretation of faults and underlying rock types (in particular, volcanic) that will provide new insights on the geologic framework, critical input to future hydrologic investigations. For example, the aeromagnetic data map the western end of the Bear Wallow Canyon fault into the sedimentary fill of Verde Valley.

Gravity data indicate the density distribution in the upper crust. In particular, gravity lows associated with Big Chino, Verde, and Williamson Valleys indicate potentially significant accumulations of low-density basin fill. More quantitative analyses of the aeromagnetic and gravity data will require two- and three-dimensional modeling and incorporate digital geologic coverages at a scale of 1:100,000 and interpreted drillers' logs.

The electrical and seismic data help evaluate: (1) the approximate depth and extent of recent alluvium overlying Tertiary and Paleozoic sediments (2) the potential contribution of shallow ground-water subflow that cannot be measured by gages or flow meters and (3) whether stream flow in losing reaches is moving as subflow or is being lost to the 
subsurface. This information will contribute to a better understanding of the stream/aquifer interaction and will help reduce future ground-water flow model uncertainty (Woodhouse and others, 2002). In addition, the electrical properties will be used as ground-truth controls for any future airborne surveys.

\section{ACKNOWLEDGMENTS}

We thank Yavapai County for financial support. We are grateful to David A. Ponce and Frank Chuang (both at the U.S. Geological Survey, Menlo Park, CA) who reviewed the manuscript. 


\section{REFERENCES}

Anderson, C.A., and Blacet, P.M., 1972a, Precambrian geology of the northern Bradshaw Mountains, Yavapai County, Arizona: U.S. Geological Survey Bulletin

And3Bson8X. PA., and Blacet, P.M., 1972b, Geologic map of the Mount Union quadrangle, Yavapai County, Arizona: U.S. Geological Survey Geologic Quadrangle Map GQ-997, scale 1:62,500.

Anderson, C.A., and Creasey, S.C., 1958, Geology and ore deposits of the Jerome area, Yavapai county, Arizona: U.S. Geological Survey Professional Paper 308, 185 p.

Anderson, Phillip, 1989, Stratigraphic framework, volcanic-plutonic evolution, and vertical deformation of the Proterozoic volcanic belts of central Arizona, in Jenney, J.P., and Reynolds, S.J., eds, Geologic evolution of Arizona: Arizona Geological Society Digest 17, p. 57-148.

Barton, C.E., Baldwin, R.T., Barraclagh, D.R., Bushati, S., Chiappini, Massimo, Cohen, Y., Coleman, R., Hulot, G., Kotze, P., Golokov, V.P., Jackson, Langel, R.A., Lowes, F.J., McKnight, D.J., MacMillan, S., Newitt, L.R., Peddie, N.W., Quinn, J.M., and Sabaka, T.J., 1996, International geomagnetic reference field, 1995 revision: Pure and Applied Geophysics, v. 147, no. 1, p. 195-202.

Bath, G.D., and Jahren, C.E., 1984, Interpretations of magnetic anomalies at a potential repository site located in the Yucca Mountain area, Nevada Test Site: U.S. Geological Survey Open-File Report 82-536, 27 p.

Blakely, R.J., 1995, Potential Theory in Gravity and Magnetic Applications: Cambridge University Press, $441 \mathrm{p}$.

Blakely, R.J., and Simpson, R.W., 1986, Approximating edges of source bodies from magnetic or gravity anomalies: Geophysics, v. 51, p. 1494-1498.

Bressler, S.L., and Butler, R.B., 1978, Magnetostratigraphy of the late Tertiary Verde Formation, central Arizona: Earth and Planetary Science Letters, v. 38, p. 319-330.

Cunion, E. J., Jr., 1985, Analysis of gravity data from the southeastern Chino Valley, Yavapai County, Arizona: Northern Arizona University Master's thesis, 110 p.

Dempsey, W.J., and Hill, M.E., 1963, Aeromagnetic map of central Yavapai County, Arizona, including the Jerome mining district: U.S. Geological Survey Geophysical Investigations Map GP-402, scale 1:62,500.

DeWitt, Ed, ed., 1987, Proterozoic ore deposits of the southwestern U.S.: Society of Economic Geologists Guidebook Series, v. 1, 189 p.

DeWitt, Ed, 1989, Geochemistry and tectonic polarity of Early Proterozoic (1700-1750 Ma) plutonic rocks, north-central Arizona, in Jenney, J.P., and Reynolds, S.J., eds., Geologic evolution of Arizona: Arizona Geological Society Digest 17, p. 149-164.

Dobrin, M.B., and Savit, C.H., 1988, Introduction to Geophysical Prospecting: McGraw-Hill Book Company, 867 p.

Eberhart-Phillips, Donna., Richardson, R.M., Sbar, M.L., and Herrmann, R.B., 1981, Analysis of the 4 February 1976 Chino Valley, Arizona, earthquake: Bulletin of Seismological Society of America, v. 71, p. 787-801.

Elston, D.P. and Young, R.A.,1991, Cretaceous-Eocene (Laramide) landscape development and Oligocene-Pliocene drainage reorganization of Transition Zone and Colorado Plateau: Journal of Geophysical Research, v. 96, no. B7, p. 12,389-12,406.

Frank, A.J., 1984, Analysis of gravity data from the Picacho Butte area, Yavapai and Coconino counties, Arizona: Northern Arizona University Masters thesis, 82 p.

Holm, R.F., Ranney, W.D.R., Witke, J.H., and Lee, K.F., 1998, Miocene volcanism and geomorphology in Verde Valley, and petrology of alkaline and mildly alkaline rocks at House Mountain shield volcano, Sedona, Arizona, in Duebendorfer, E.M., ed., 
Geologic excursions in northern and central Arizona: Northern Arizona University, p. 1-26.

Krieger, M.H., 1965, Geology of the Prescott and Paulden quadrangles, Arizona: U.S. Geological Survey Professional Paper 467, 127 p.

Krieger, M.H., 1967a, Reconnaisance geologic map of the Ashfork quadrangle, Yavapai and Coconino counties, Arizona: U.S. Geological Survey Miscellaneous Geologic Investigations Map I-499, scale 1:62,500.

Krieger, M.H., 1967b, Reconaissance geologic map of the Picacho Butte quadrangle, Yavapai and Coconino counties, Arizona: U.S. Geological Survey Miscellaneous Investigations Map I-500, scale 1:62,500.

Langenheim, V.E., Duval, J.S., Wirt, Laurie, and Dewitt, Ed, 2000, Preliminary report on geophysics of the Verde River headwaters region, Arizona: U.S. Geological Survey Open-File Report 00-403, 28 p. (http:// wrgis.wr.usgs.gov/open-file/of00-403).

Leighty, R.S., 1998, Tertiary volcanism, sedimentation, and tectonics of the central Arizona Transition Zone, in Duebendorfer, E.M., ed., Geologic excursions in northern and central Arizona: Northern Arizona University, p. 59-96.

McNeill, J.D., 1980, Electromagnetic terrain conductivity measurements at low induction numbers: Mississauga, Ontario, Canada, Geonics Ltd. Technical Note TN-6, 15 p.

Menges, C.M., and Pearthree, P.A., 1983, Map of neotectonic (latest PlioceneQuaternary) deformation in Arizona: Arizona Bureau of Geology and Mineral Technology, Open-File Report 83-22, 48 p.

National Geophysical Data Center, 1999, Land and Marine Gravity CD-ROMS, compiled by David Dater, Dan Metzger, and Allen Hittelman, Boulder, CO.

Nations, J.D., Hevly, R.H., Landye, J.J., and Blinn, D.W., 1981, Paleontology, paleoecology, and depositional history of the Miocene-Pliocene Verde Formation, Yavapai county, Arizona in Stone, Claudia and Jenney, J.P., eds., Arizona Geological Society Digest, v. 13, p. 133-150.

Oppenheimer, J.M., and Sumner, J.S., 1980, Depth-to-bedrock map, Basin and Range province, Arizona: Laboratory of Geophysics, University of Arizona, scale

Owlen-1000,0,08.J., and Bell, C.K., 1983, Appraisal of water resources in the Upper Verde River area, Yavapai and Coconino Counties, Arizona: Arizona Department of Water Resources Bulletin 2, 219 p.

Pearthree, P.A., 1998, Quaternary fault data and map for Arizona: Arizona Geological Survey Open-File Report 98-24, 122 p.

Peirce, H.W., and Scurlock, J.R., 1972, Arizona well information: Arizona Bureau of Mines Bulletin 185, $195 \mathrm{p}$.

Reynolds, S.J., 1988, Geologic map of Arizona: Arizona Geological Survey Map 26, scale $1: 1,000,000$.

Richard, S.M., and Kneale, S.M. (eds.), 1998, Geologic map of Arizona, GIS database: Arc/INFO export file (.e00) format, 2 disks, $10 \mathrm{p}$.

Rimrock Geophysics Inc., 1995, Seismic refraction interpretation programs: Lakewood, Colorado, Rimrock Geophysics Inc., v.p.

Shoemaker, E.M., Squires, R.L., and Abrams, M.J., 1978, Bright Angel and Mesa Butte fault systems of northern Arizona in Cenozoic Tectonics and Regional Geophysics of the Western Cordillera, Smith, R.B., and Eaton, G.P., eds.: Geological Society of America Memoir 152, p. 341-367.

Simpson, R.W., Jachens, R.C., Blakely, R.J., and Saltus, R.W., 1986, A new isostatic residual gravity map of the conterminous United States with a discussion on the significance of isostatic residual anomalies: Journal of Geophysical Research, v. 91, p. 8348-8372.

Smith, M.A., 1984, Analysis of gravity data from the Verde Valley, Yavapai county, Arizona: Northern Arizona University Master's thesis, 57 p. 
Sweeney, R.E., and Hill, P.L., 2001, Arizona aeromagnetic and gravity maps and data: A web site for distribution of data: U.S. Geological Survey Open-File Report 01-0081 (http:// greenwood.cr.usgs.gov/pub/open-file-reports/ofr-01-0081).

Thorstenson, D.J., and Beard, L.S., 1998, Geology and fracture analysis of Camp Navajo, Arizona Army National Guard, Arizona: U.S. Geological Survey Open-File Report 98-242, 42 p.

Twenter, F.R., and Metzger, D.G., 1963, Geology and ground water in Verde Valley_the Mogollon rim region, Arizona: U.S. Geological Survey Bulletin 1177, 132

Typer, G. N., 1984, Geology and petrogenesis of the Sullivan Buttes latite, Yavapai County, Arizona; field and geochemical evidence: Austin, University of Texas, Ph.D. dissertation, $286 \mathrm{p}$.

U.S. Geological Survey, 1981, Aeromagnetic map of the Arnold Mesa area, Arizona: U.S. Geological Survey Open File Report 81-089, 1 sheet, scale 1:62,500.

U.S. Geological Survey, 1982, Aeromagnetic map of the Rattlesnake area, Arizona: U.S. Geological Survey Open File Report 82-658, 1 sheet, scale 1:62,500.

Wilson, E.D., 1939, Precambrian Mazatzal revolution in central Arizona: Geological Society of America Bulletin, v. 50, p. 1131-1163.

Wirt, Laurie, and Hjalmarson, H.W., 2000, Sources of springs supplying base flow to the Verde River headquarters, Yavapai County, Arizona: U.S. Geological Survey OpenFile Report 99-0378, (http://greenwood.cr.usgs.gov/pub/open-file-reports/ofr-990378), $54 \mathrm{p}$.

Woodhouse, B.G., Flynn, M.E., Parker, J.T.C., and Hoffmann, J.P., 2002, Investigation of the geology and hydrology of the upper and middle Verde watershed of central Arizona: A project of the Arizona Rural Watershed Initiative: U.S. Geological Survey Fact Sheet 059-02, 4 p. 


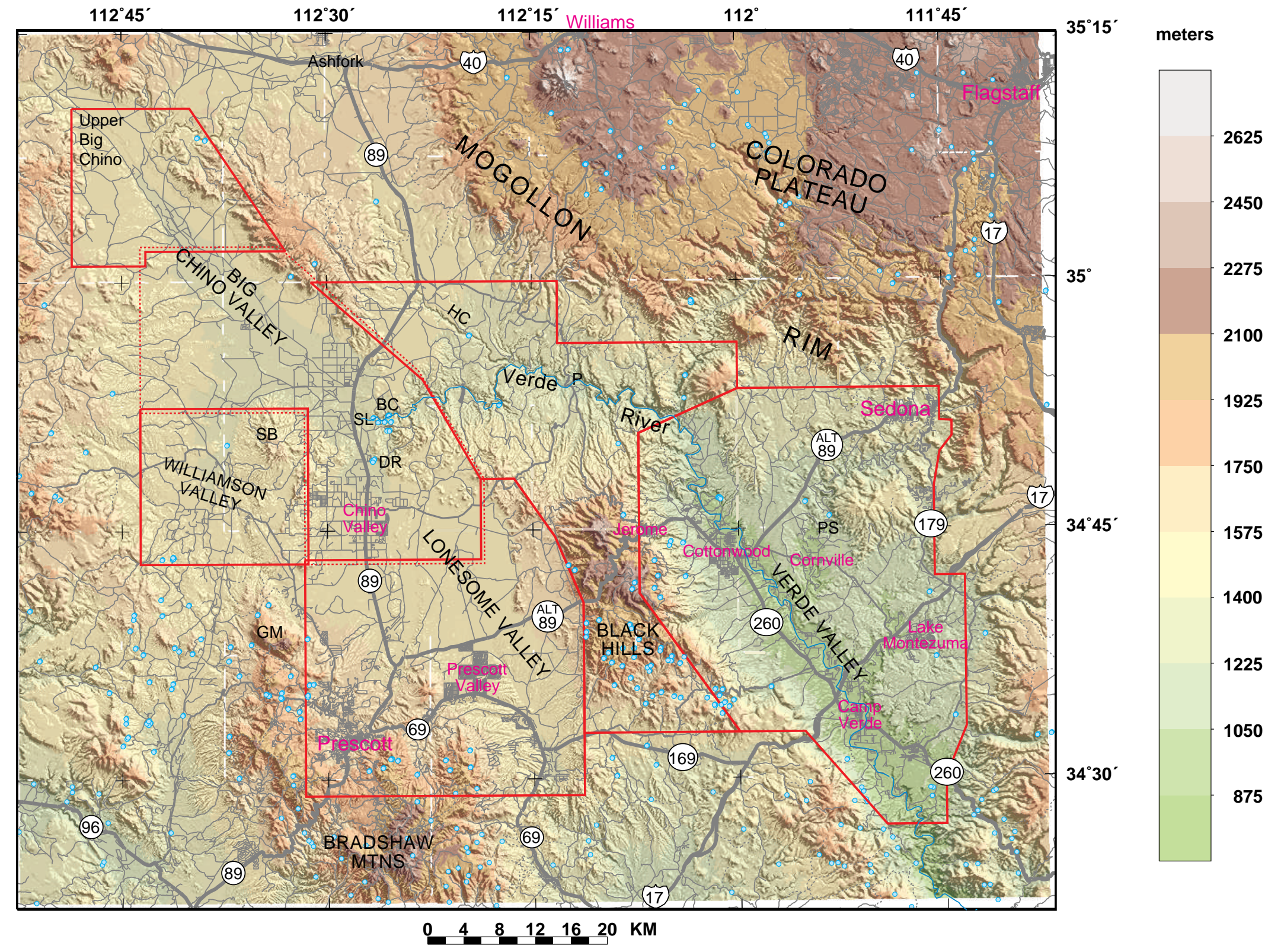

Figure 1. Index map of study area. Red lines outline areas flown for new aeromagnetic survey. Dotted red line indicates extent of 1999 survey (see Langenheim and others, 2000). Blue circles denote springs. Towns and cities in magenta lettering. BC, Big Chino springs, DR, Del Rio springs; GM, Granite Mountain; HC, Hell Canyon; P, Perkinsville; PS, Page Springs; SB, Sullivan Buttes; SL, Sullivan Lake. 


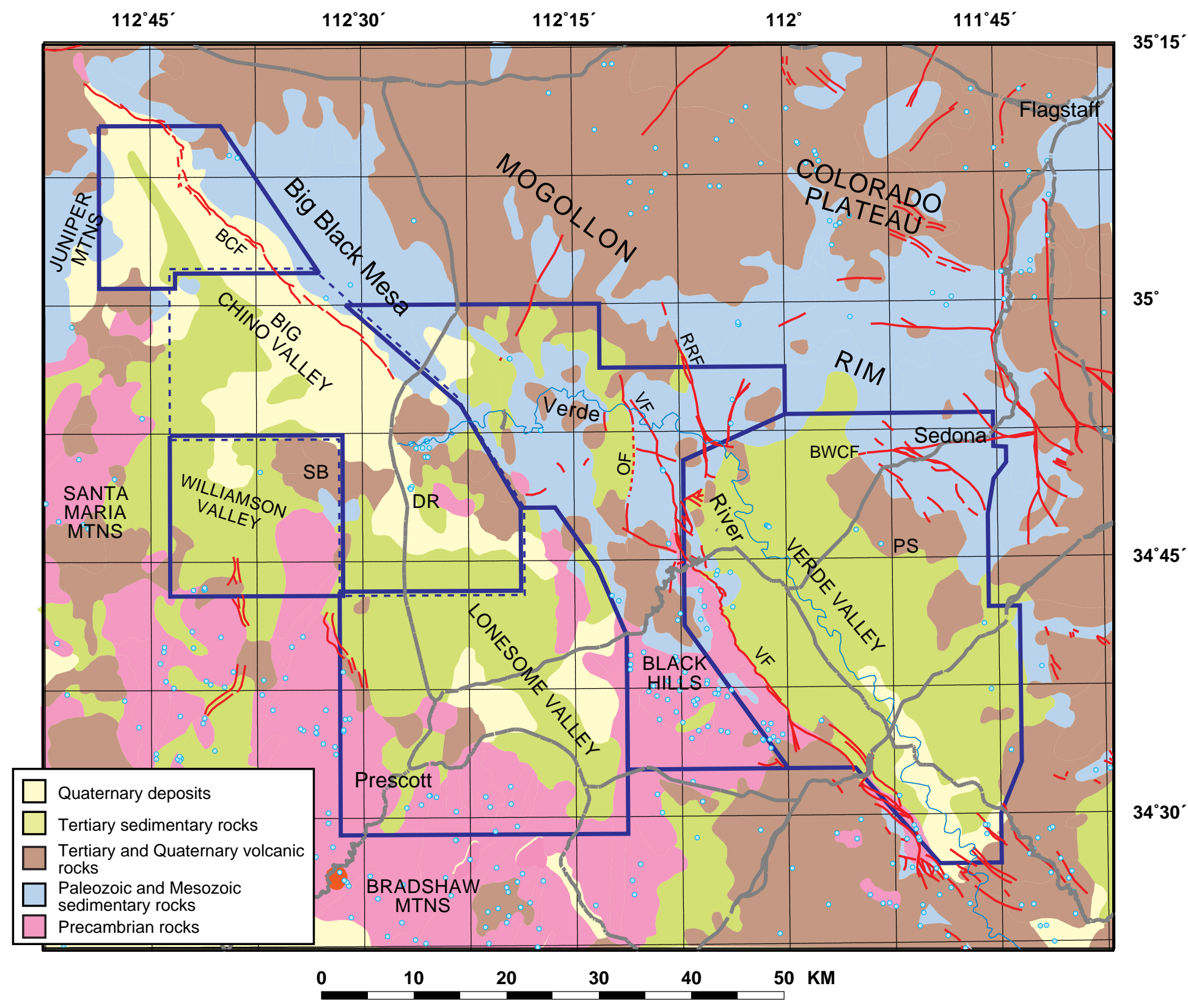

Figure 2. Simplified geologic map of the Yavapai county study area. Geology abridged from Reynolds (1988) and Richard and Kneale (1993). Dark blue outlines aeromagnetic survey boundary; dotted dark blue line shows extent of 1999 high-resolution survey. Springs are blue circles. Heavy gray lines are highways. BWCF, Bear Wallow Canyon fault; BCF, Big Chino fault RRF, Railroad fault; OF, Orchard fault; VF, Verde fault. Faultsfrom Pearthree (1998), Twenter and Metzger (1963), and Owens-Joyce and Bell (1983). 


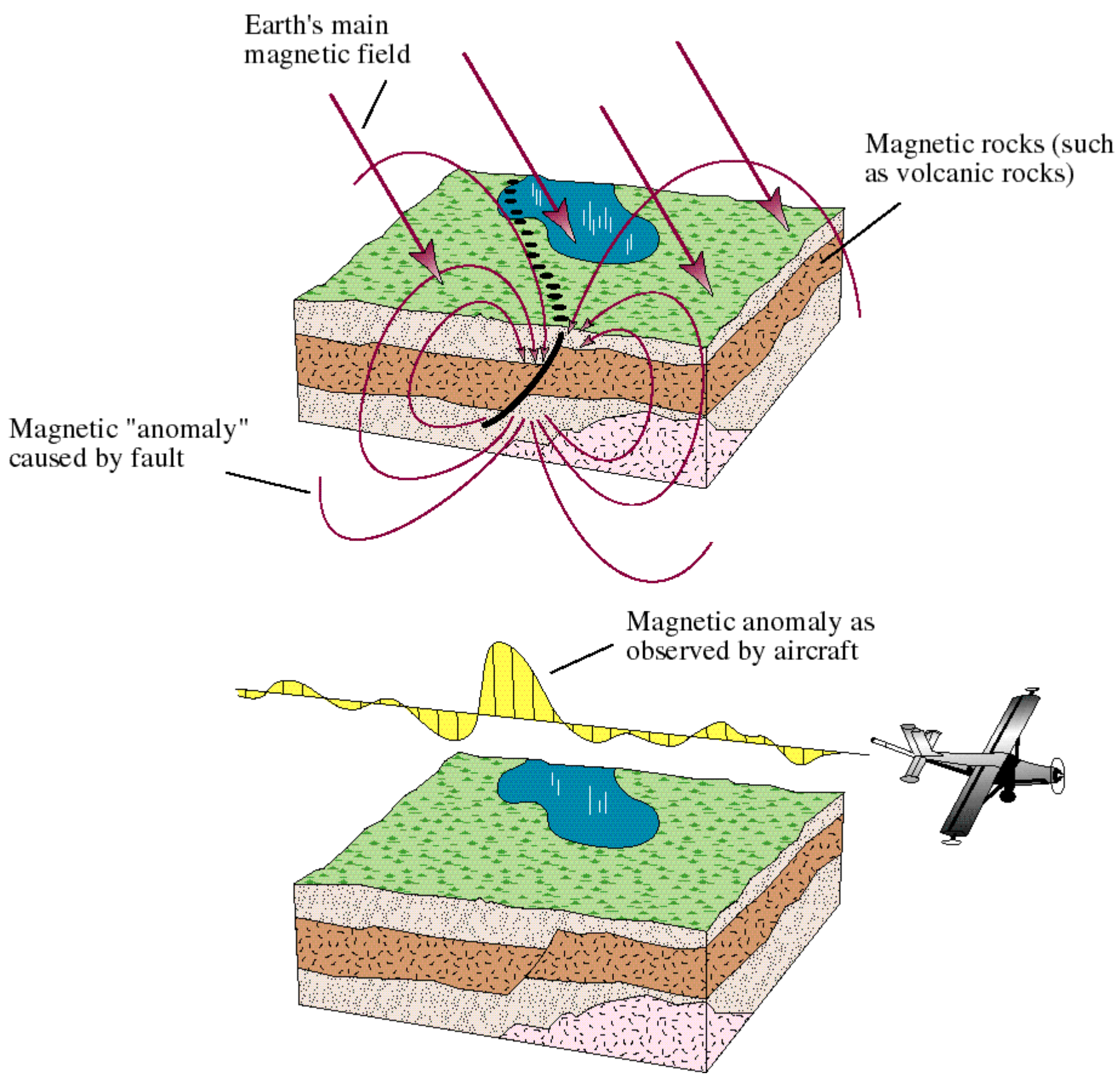

Figure 3. Cartoon illustration of the magnetic method. Magnetic rocks (such as the faulted volcanic unit shown here) produce small magnetic fields that perturb the much larger magnetic field originating from the Earth's core. Much can be learned about magnetic rocks by measuring the magnetic field near the topographic surface, though those rocks may be completely concealed. Courtesy of R.J. Blakely (U. S. Geological Survey). 


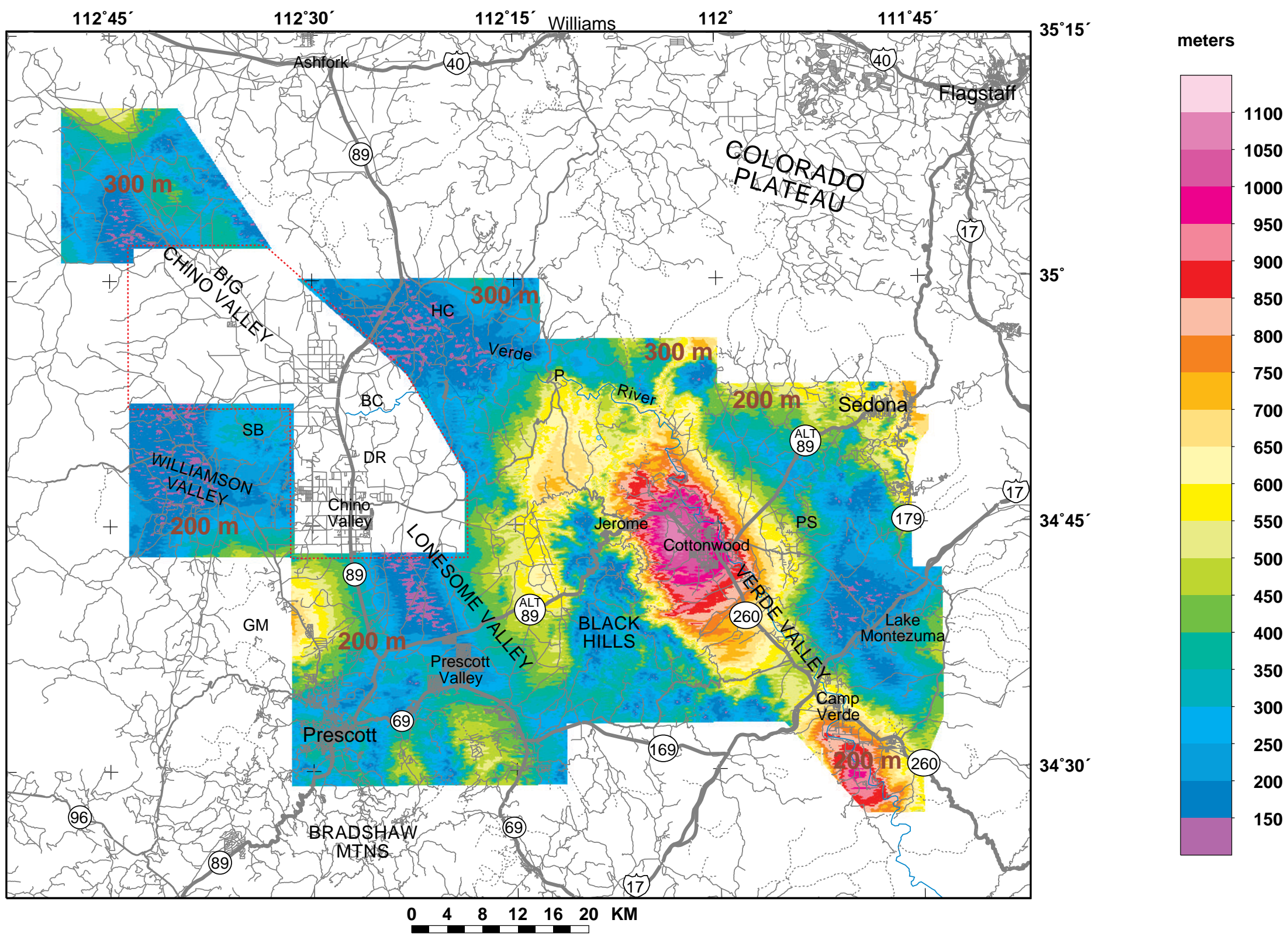

Figure 4. Radar altimetry of new survey (height above terrain). Dotted red line indicates extent of 1999 survey (see Langenheim and others, 2000). BC, Big Chino springs, DR, Del Rio springs; GM, Granite Mountain; HC, Hell Canyon; P, Perkinsville; PS, Page Springs; SB, Sullivan Buttes. Numbers in brown refer to line spacing. 


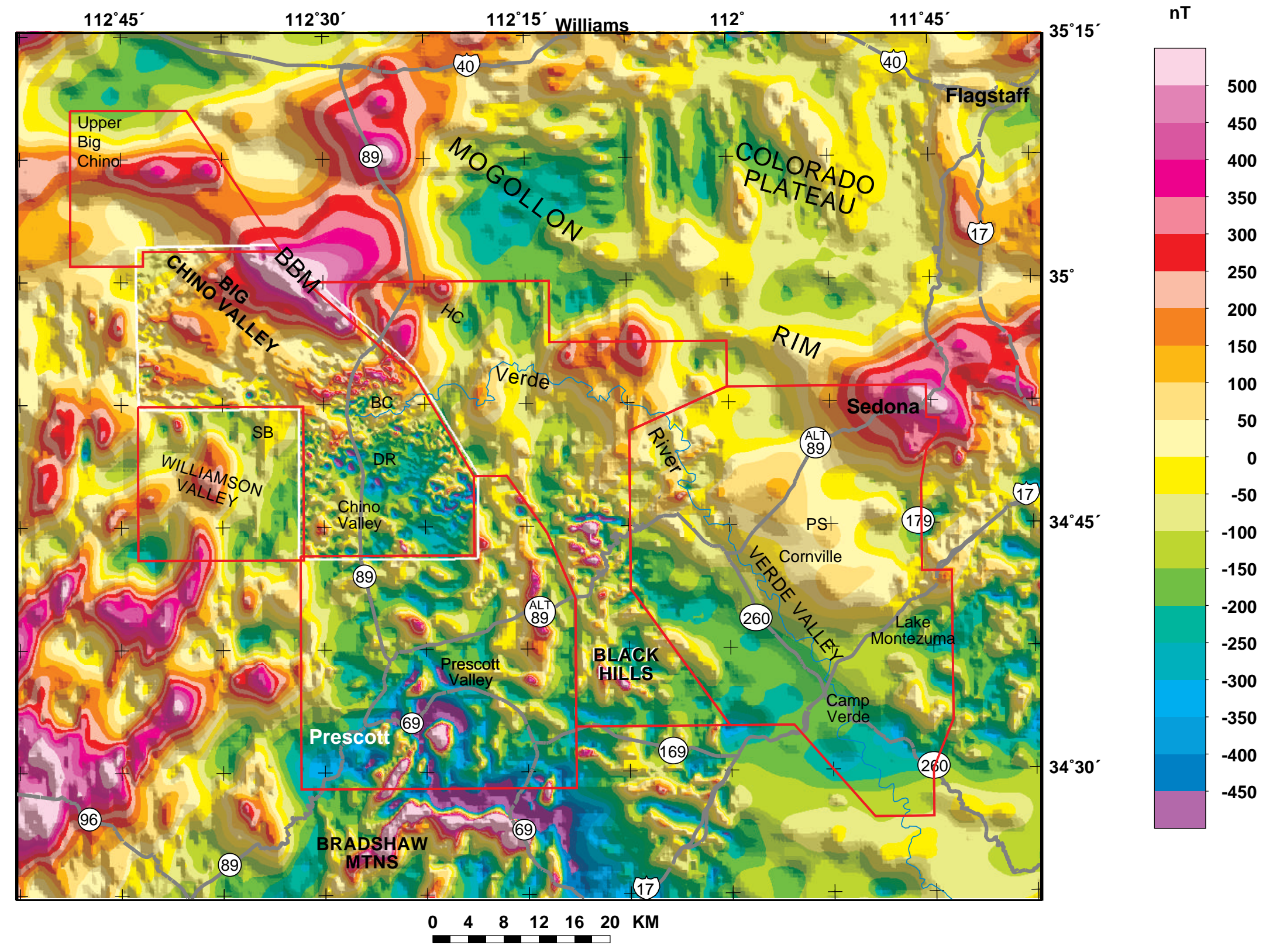

Figure 5a. Aeromagnetic map before incorporation of new data (outline shown in red). Heavy gray lines are highways. White line is 1999 high-resolution aeromagnetic survey.. BBM, Big Black Mesa. 


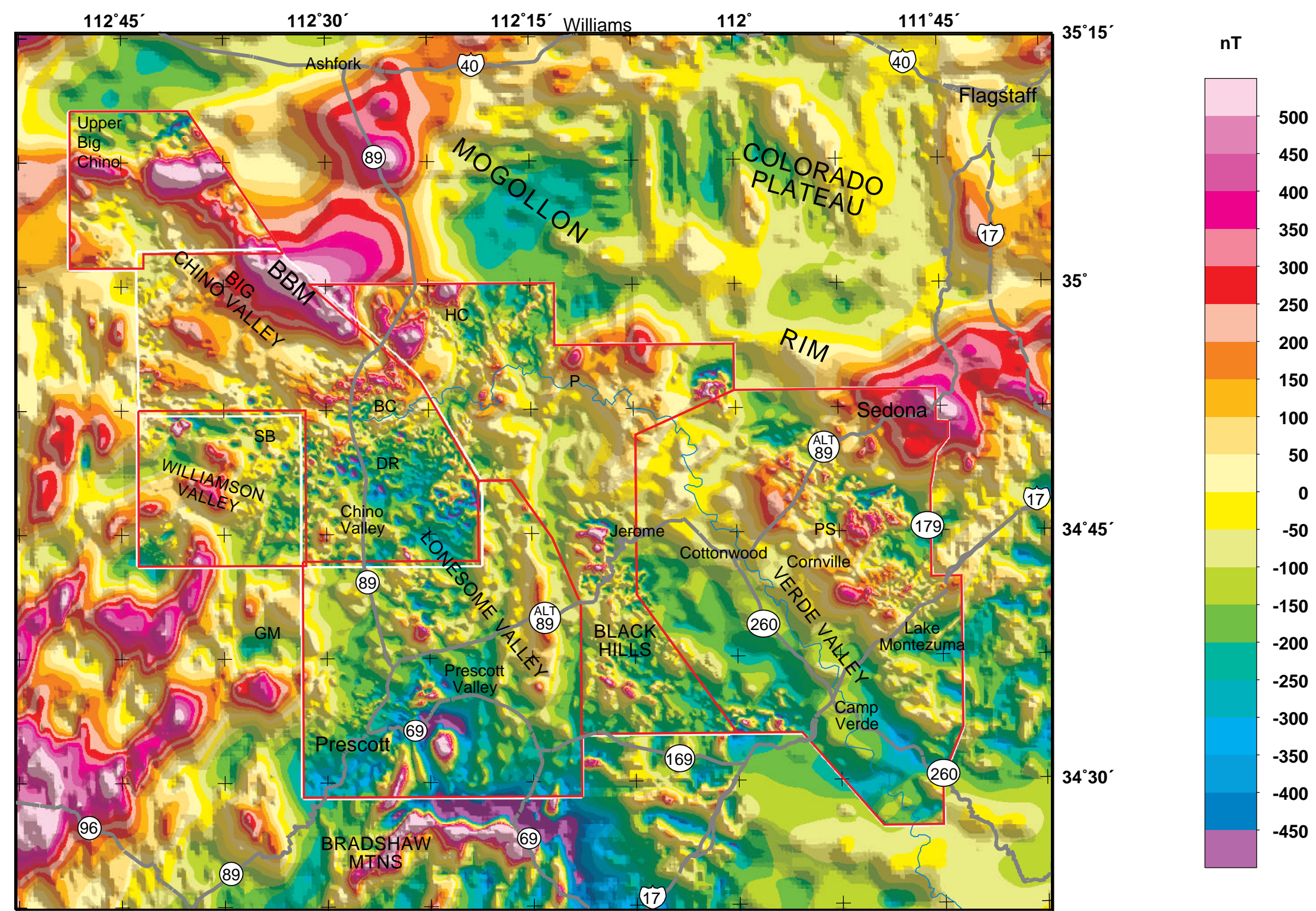

$$
\begin{array}{lllllll}
0 & 4 & 8 & 12 & 16 & 20 & \mathrm{KM}
\end{array}
$$

Figure 5b. Aeromagnetic map with new data incorporated. BBM, Big Black Mesa; BC, Big Chino springs, DR, Del Rio springs; GM, Granite Mountain; HC, Hell Canyon; P, Perkinsvile; PS, Page Springs; SB, Sullivan Buttes. Heavy gray lines are highways. White line outlines 1999 high-resolution survey. 


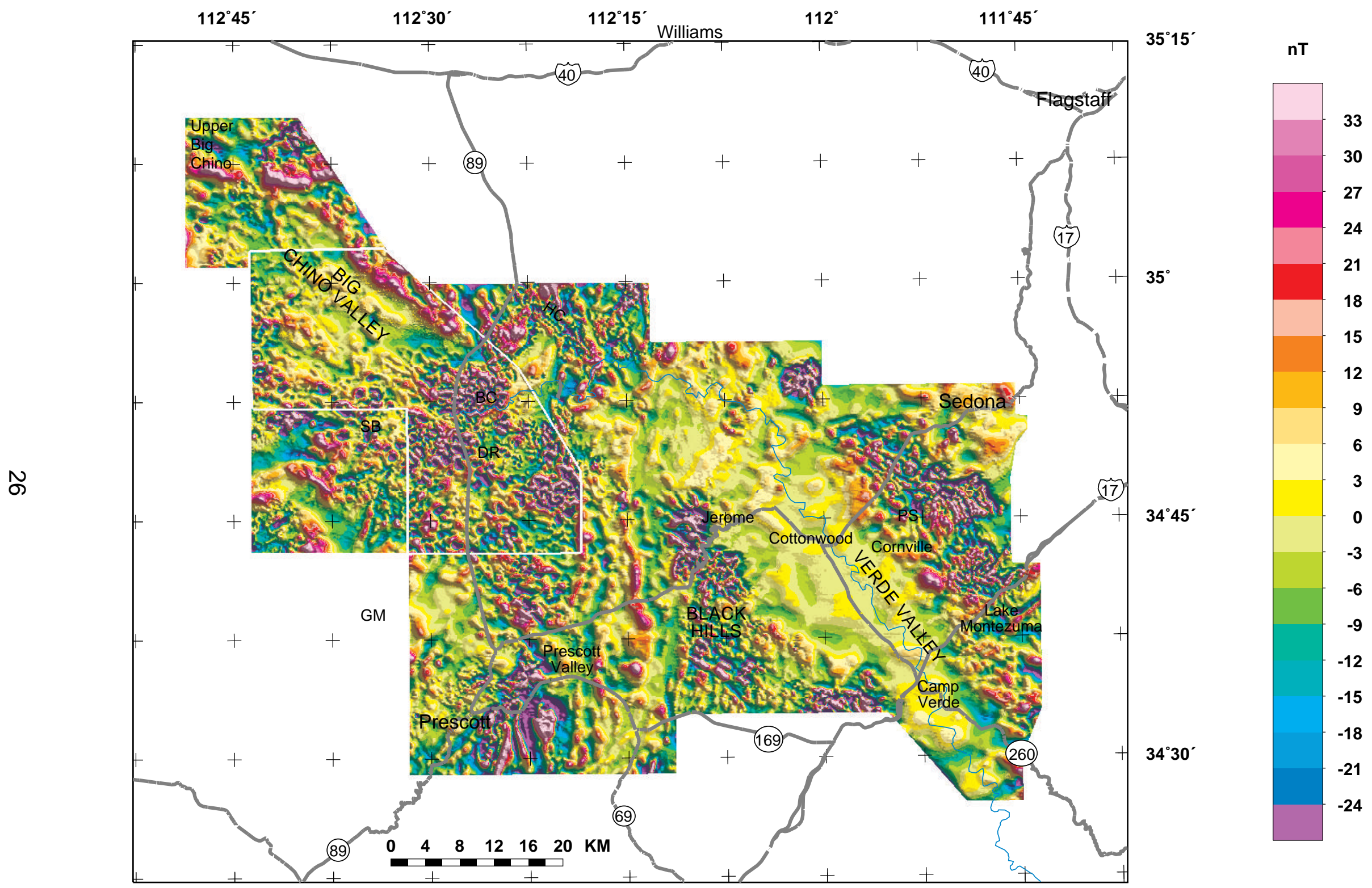

Figure 6. Aeromagnetic anomaly map where data have been filtered to enhance shallow sources. Short-wavelength, high-amplitude anomalies occur where the amplitude of the anomaly changes abruptly (i.e. where pink areas are immediately adjacent to purple areas). 


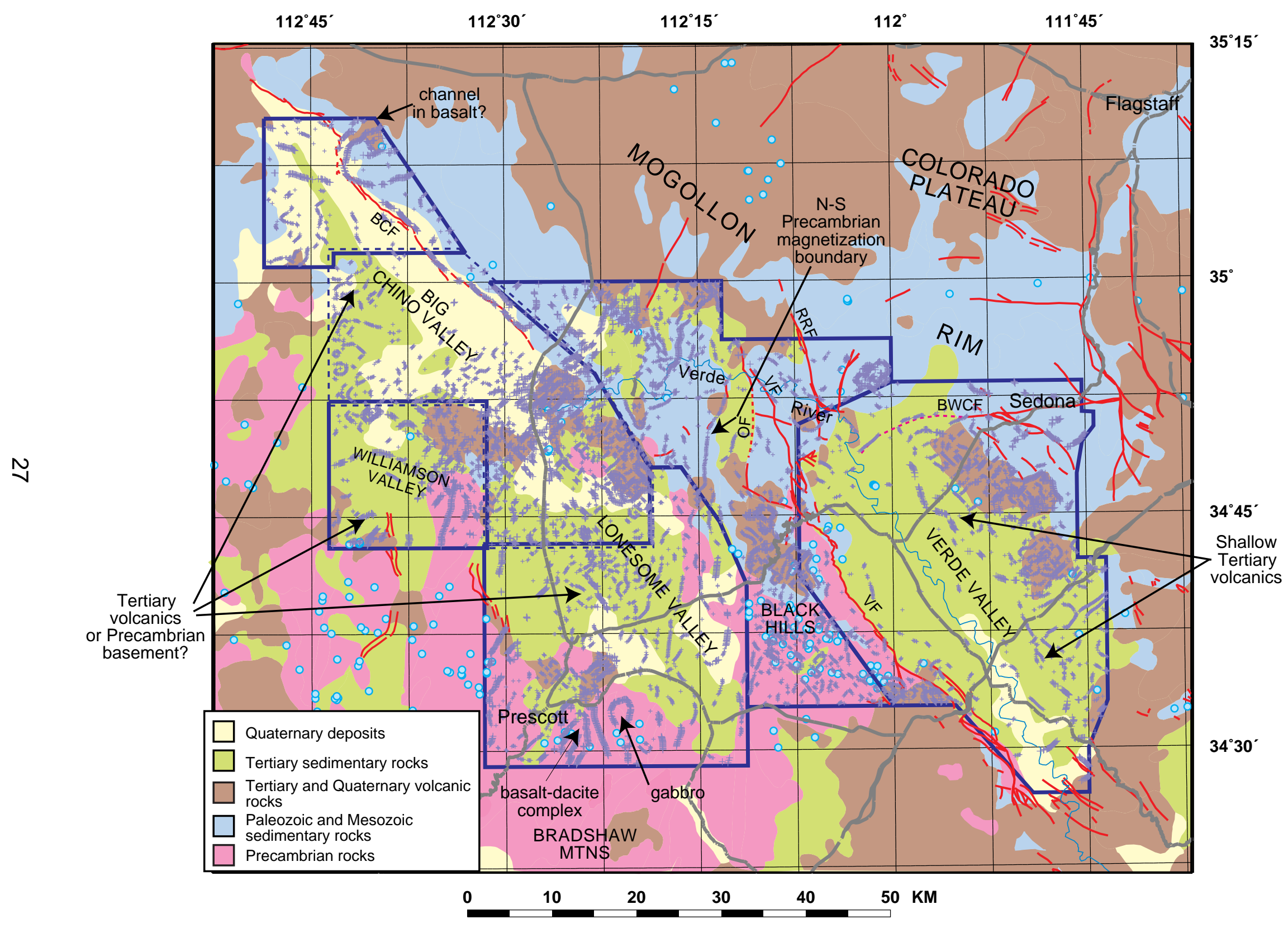

Figure 7. Magnetization boundaries (blue crosses) superimposed on simplified geology. Dark blue outlines aeromagnetic survey boundary; dotted dark blue line shows extent of 1999 high-resolution survey. Springs are blue circles. Heavy gray lines are highways. Red lines are faults. BWCF, Bear Wallow Canyon fault; BCF, Big Chino fault; RRF, Railroad fault; OF, Orchard fault; VF, Verde fault. Dotted red line is extension of BWCF on the basis of the magnetic data. 


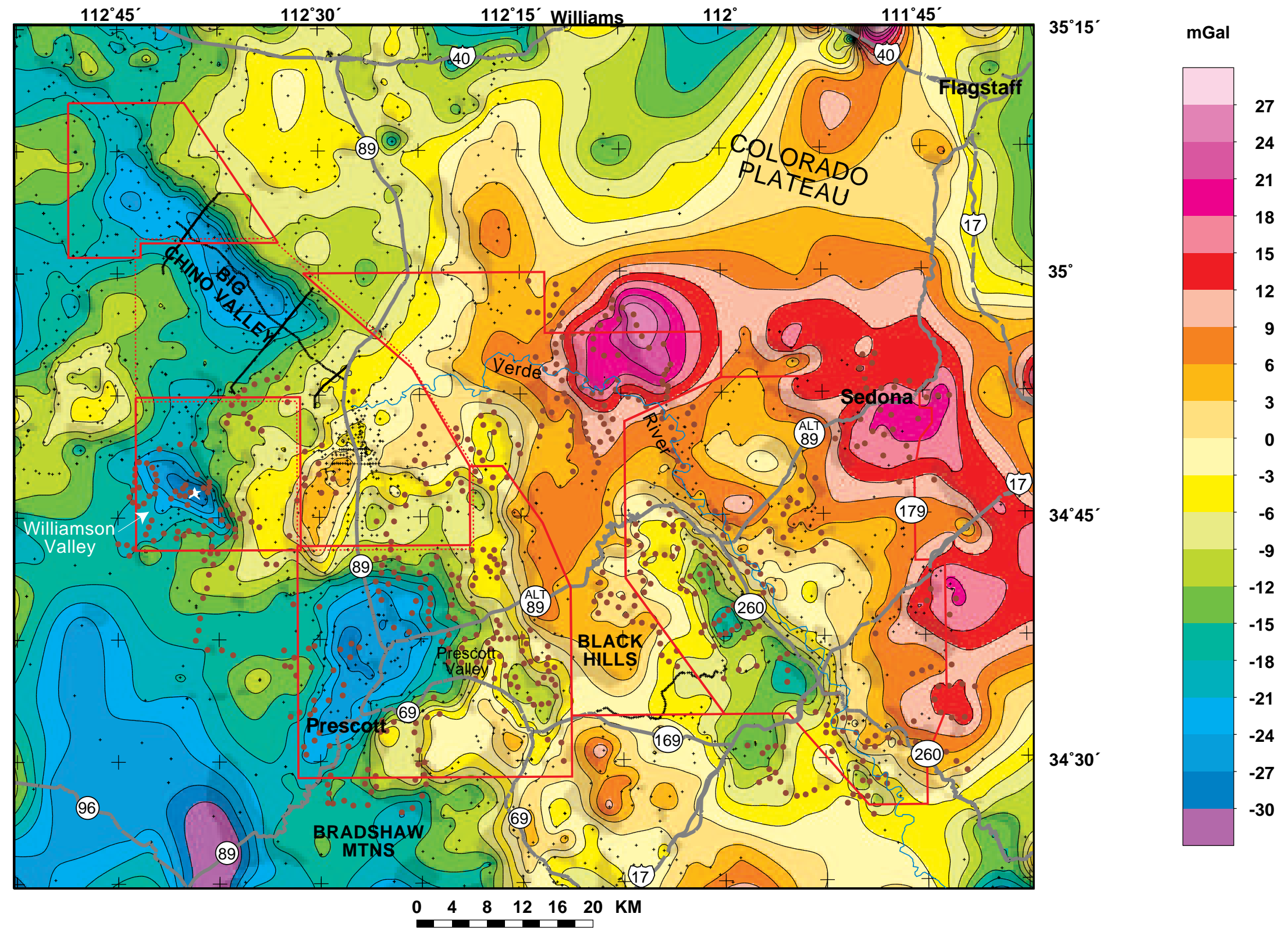

Figure 8. Isostatic residual gravity map of the study area. New aeromagnetic survey outlined in red; 1999 high-resolution survey in dashed red line. Crosses are previously collected gravity data; new data are brown circles. Heavy gray lines are highways. White star in Williamson Valley gravity low is drillhole that penetrated $460 \mathrm{~m}$ without penetrating basement. 


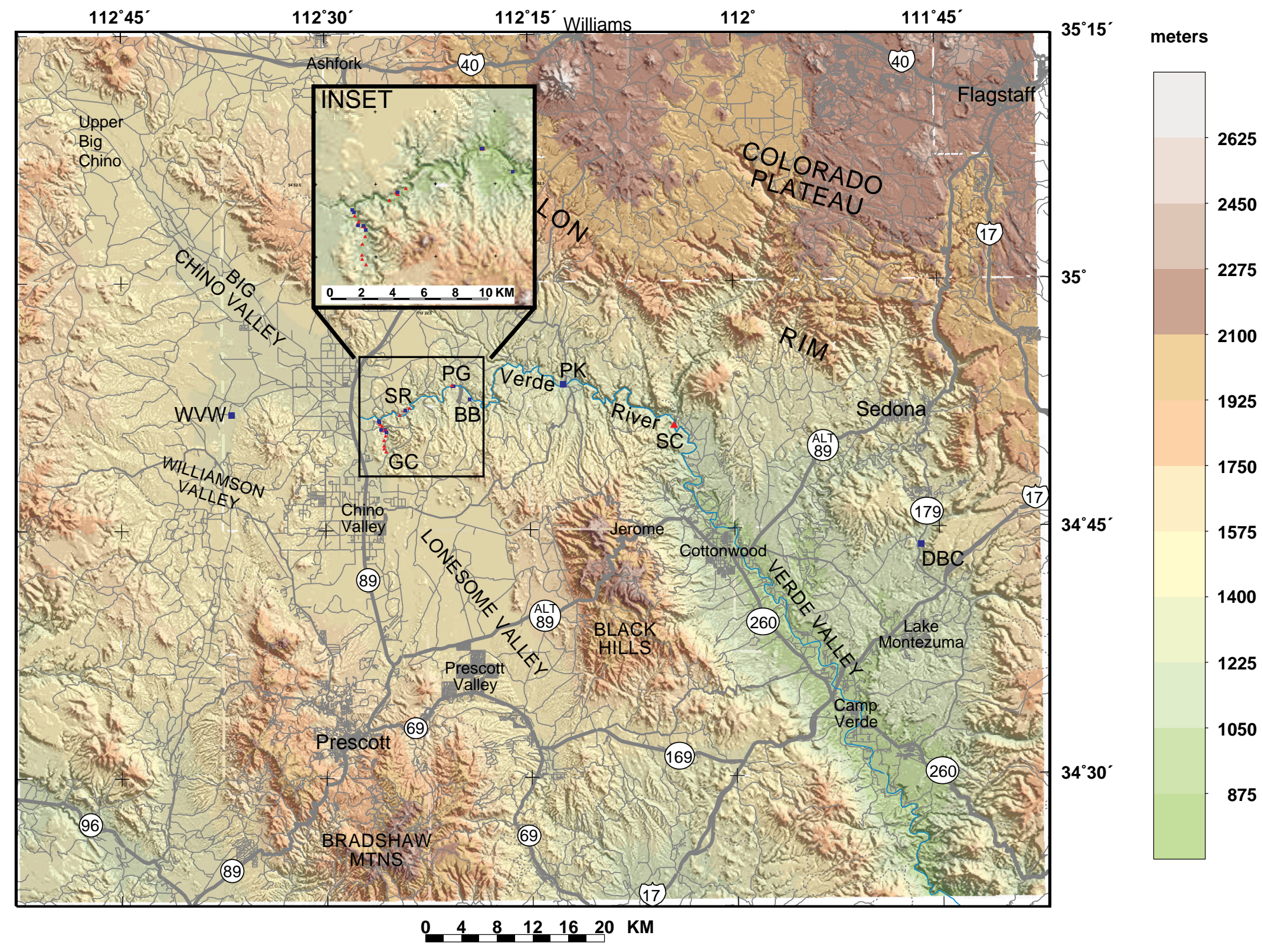

Figure 9. Site map of shallow geophysical surveys. Blue boxes show locations of seismic-refraction surveys; red triangles, shallow electromagnetic surveys. Survey location abbreviations: BB, Bull Basin; DBC, Dry Beaver Creek; GC, Granite Creek, PG, Paulden stream gage, PK, Perkinsville, SC, Sycamore Creek; SR, Stewart Ranch, WVW, WIlliamson Valley Wash. 